\section{JOURNEYS IN THE PAMIRS AND ADJACENT COUNTRIES.}

THIS was the subject of the paper read at the meeting of the Royal Geographical Society, on Monday, by Captain F. E. Younghusband. The author described two journeys, one in I889 across the Kárákorum and into the Pamir, the other in 1890 to Yarkand and Kashgar, and south to the Pamirs again.

"The country," he said, "which I now wish to describe to you is that mountainous region lying to the north of Kashmir, which from the height, the vastness, and the grandeur of the mountains, seems to form the culminating point of Western Asia. When that great compression in nature took place this seems to have been the point at which the great solid crust of the earth was scrunched and crushed together to the greatest extent, and what must have formerly been level peaceful plains such as we see to the present day on either hand, in India and in Turkistan, were pressed and upheaved into these mighty mountains, the highest peaks of which are only a few hundred feet lower than Mount Everest, the loftiest point on this earth. It was amongst the peaks and passes, the glaciers and torrents of this awe-inspiring region, and anon over the plain-like valleys and by the still, quiet lakes of the Pamirs that my fate led me in the journeys which I have now come before you to describe."

Starting from Leh, in Ladak, Captain Yuunghusband's first objective point was Shahidula. This place is situated on the trade route to Yark and, and is 240 miles distant from Leh. This he left on September 3, to explore the country up to the Tagh-dum-bash Pamir.

The route now led up the valley of a river, on which were several patches of fine grazing, and till last year this had been well inhabited, but was now deserted on account of Kanjuti raids. The valley is known by the name of Khál Chuskún. Chuskún in Turki means resting-place, and Kbál is the name of a holy man from Bokhara, who is said to have rested here many years ago. The mountains bounding the north of this valley are very bold and rugged, with fine upstanding peaks and glaciers; but the range to the south, which Hayward calls the Aktágh Range, was somewhat tame in character, with round mild sumaits and no glaciers. The Sokhbulák is an easy pass, and from its summit to the east could be seen the snowy range of the western Kuenlun Mountains, while to the west appeared a rocky mass of mountains culminating in three fine snowy peaks which Hayward mistook as belonging to the main Mustagh Range, but which in fact in no way approach to the height and magnificence of those mountains, and really belong to the Aghil Range, which is separated from the Mustagh Mountains by the valley of the Oprang River.

On September II, the party crossed the remarkable depression in the range which is known as the Aghil Pass.

"From here is obtained one of the grandest views it is possible to conceive; to the south-west you look up the valley of the Oprang River, which is bounded on either side by ranges of magnificent snowy mountains, rising abruptly from either bank, and far away in the distance could be seen the end of an immense glacier flowing down from the main range of the Mustagh Mountains. This scene was even more wild and bold than I had remembered it on my former journey, the mountains rising up tier upon tier in a succession of sharp needle-like peaks bewildering the eye by their number, and then in the background lie the great ice mountains - white, cold, and relentless, defying the hardiest traveller to enter their frozen clutches. I determined, however, to venture amongst them to examine the glaciers from which the Oprang River took its rise, and leaving my escort at the foot of the Aghil Pass, set out on an exploration in that direction. The first march was easy enough, leading over the broad pebbly bed of the Oprang River. Up one of the gorges to the south we caught a magnificent view of the great

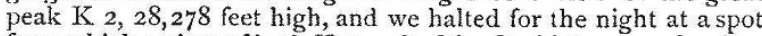
from which a view of both K 2 and of the Gushirbrum peaks, four of which are over 26,000 feet, was visible. On the following day our difficulties really began. The first was the great glacier which we had seen from the Aghil Pass; it protruded right across the valley of the Oprang River, nearly touching the cliffs on the right bank; but fortunately the river had kept a way for itself by continually washing away the end of the glacier, which terminated in a great wall of ice 150 to 200 feet high. This glacier runs down from the Gushirbrum in the distance towering up to a height of over 26,000 feet. The passage round the end of the glacier was not unattended with danger, for the stream was swift and strong, and on my own pony I had to reconnoitre very carefully for points where it was shallow enough to cross, while there was also some fear of fragments from the great icewall falling down on the top of us when we were passing along close under it. After getting round this obstacle we entered a gravel plain, some three-quarters of a mile broad, and were then encountered by another glacier running across the valley of the Oprang River. This appeared to me to be one of the principal sources of the river, and I determined to ascend it. Another glacier could be seen to the south, and yet a third coming in a south-east direction, and rising apparently not very far from the Kárákorum Pass. We were, therefore, now in an ice-bound region, with glaciers in front of us, glaciers behind us, and glaciers all around us. Heavy snow-clouds too were unfortunately collecting to increase our difficulties, and I felt that we should have a hard task before us. On first looking at one of these glaciers it would appear impossible to take ponies up them, but the sides are always covered with moraine, and my experience in the exploration of the Mustagh Pass in 1887 showed that by carefully reconnoitring ahead, it was generally possible to take the ponies for a considerable distance at least up such glaciers; and as the one we had now reached seemed no worse than others, and there appeared a gap in the range which looked as if it might be a pass, I took my ponies on, and after three days' scrambling on the ice, reached the foot of the supposed pass, and started at 3.30 on the following morning to find if it was at all practicable."

Captain Younghusband was, however, obliged to return after reaching a height of $\mathrm{I} 7,000$ feet, and he decided to return to his camp on the Oprang River. He thus describes the glaciers from which this river takes its rise :-

"The length of this glacier is 18 miles, and its average breadth half a mile; it is fed by three smaller glaciers on the west and one on the east. At its upper part, immediately under the pass, it is a smooth undulating snow-field about a mile and a half in width. Lower down this névé is spilt up into crevasses, which increase in size the further down we get. Then the surface gradually breaks up into a mass of ice-domes, which lower down become sharp needle.like pinnacles of pure white ice. On each side lateral gravel moraines appear, and other glaciers join, each with its centre of white ice-peaks and its lateral moraines, and preserving each its own distinct course down the valley, until some three miles from its termination in the Oprang River, when the ice-peaks are all melted down and the glacier presents the appearance of a billowy mass of moraine, and would look like a vast collection of gravel heaps, were it not that you see, here and there, a cave or a cliff of ice, showing that the gravel forms really only a very thin coating on the surface, and that beneath is all pure solid ice. This ice is of opaque white, and not so green and transparent as other glaciers I have seen, and the snow at the head of the glacier was different from any $I$ have seen before; for beneath the surface, or when it was formed into lumps, it was of the most lovely pale transparent blue. I must mention, too, that every flake of snow that fell in the storm was a perfect hexagonal star, most beautiful and delicate in form. The mountains on either side of the valley, especially on the eastern side, are extremely rugged and precipitous, forming little or no resting-place for the snow, which drains off immediately into the glacier below. The western range, the main Mustagh Range, was enveloped in clouds nearly the whole time, and I only occasionally caught a glimpse of some peak of stupendous height, one of them, the Gushirbrum, over 26,000 feet, and others 24,000 feet. The snowfall on these mountains must be very considerable, and it seems that this knot of lofty mountains attracts the great mass of the snow.clouds, and gets the share which ought to fall on the Kárákorum, while these latter, being lower, attract the clouds to a less degree, and are in consequence almost bare of snow."

After some further exploration of the glaciers, rivers, and passes in this wild region, Captain Younghusband returned to India by way of Kashmir. In the summer of 1890 , he once more made his way northwards throngh Kashmir, with a companion, Mr. Macartney. They reached Yarkand on August 3I.

"After a rest of two or three weeks at Yarkand," Captain Younghusband went on to say, "Macartney and I left our companions and started for a trip round the Pamirs. Approaching this interesting region from the plains of Kashgaria, one sees clearly how it has acquired the name of Bam-i-dunya, or Roof of the World. The Pamir Mountains rise apparently quite suddenly out of the plain from a height of 4000 feet above sea-

$$
\text { No. I } 163 \text {, VOL. 45] }
$$


level at their base to over 25,000 feet at their loftiest summits a massive wall of rucks, snow, and ice. Mounting this wall the traveller comes on to the Bam-i-dunya, which would perhaps be better translated as the 'upper story' of the world. Houses in Turkistan are flat-roofed, and you ascend the outer wall and sit out on the roof, which thus makes an upper story, and it appears to me that it was in this sense that the Pamir region was called the Roof of the World. The name, indeed, seems singularly appropriate, for once through the gorges which lead up from the plains, one enters a region of broad open valleys separated by comparatively low ranges of mountains. These valleys are known as Pamirs-Pamir being the term applied by the natives of those parts to a particular kind of valley. In the Hindu Kush and Himalayan region the valleys as a rule are deep, narrow, and shut in. But on the Roof of the World they seem to have been choked up with the déuris falling from the mountains on either side, which appeared to me to be older than those further south, to have been longer exposed to the wearing process, and to be more worn down--in many parts, indeed, being rounded off into mere mounds, reminding one very much of Tennyson's lines :-

$$
\begin{gathered}
\text { "' "The hills are shadows, and they flow } \\
\text { From form to form, and nothing stands; } \\
\text { They melt like mist; the solid lands, } \\
\text { Like clouds they shape themselves and go.' }
\end{gathered}
$$

The valleys have thus been filled up faster than the rainfall has been able to wash them out, and so their buttoms are sometimes as much as four or five miles broad, almost level, and of considerable height above the sea. The Tagh-dum-bash Pamir runs as low as 10,300 feet, but on the other hand, at its upper extremity the height is over 15,000 feet; and the other Pamirs vary from twelve or thirteen to fourteen thousand feet above sealevel. That is, the bottoms of these Pamir valleys are level with the higher summits of the Alps.

"As might be expected, the climate is very severe. I have only been there in the autumn, and can therefore speak from personal experience of that season only; but I visited them in three successive years, and have seen ice in the basin of my tent in August. I have seen the thermometer at zero (Fahrenheit) at the end of September, and $18^{\circ}$ below (that is, $50^{\circ}$ of frost) at the end of October. The snow on the valley bottoms does not clear away before May is well advanced. June and July and the beginning of August are said to be pleasant, though with chilly nights; and then, what we in England might very justly call winter, but which, not to hurt the feelings of the hardy Kirghiz who inhabit these inhospitable regions all the year round, we will, for courtesy's sake, call autumn, commences."

Captain Younghusband and Mr. Macartney advanced up those long gravel desert slopes which lead out of the plains of Turkistan, and then through the lower outer ranges of hills covered with a thick deposit of mud and clay, which Captain Younghusband believes to be nothing else than the dust of the desert, which is ever present in the well-known haze of Turkistan, deposited on the mountain-sides; then over the Kara-dawan, Kizil-dawan, and Torat Passes; through the narrow defile known as the Tangitar, where one has to force the ponies up a deep violent stream rushing over huge boulders between precipitous rocky cliffs, in which they noticed large square holes pierced, suggesting to them that in former days this, the high road between Eastern and Western Asia, was probably improved by having a bridge over this difficult and dangerous part; then over the Chichiklik and Koh-mamak Passes and the Tagarma Plain, til they reached the neighbourhood of Tash-kurgan, the northernmost point of Captain Younghusband's explorations in the previous year. Passing through the Little Pamir, they struck the Alichur Pamir near Chadir-tash at its eastern extremity, and from there they looked down a broad level valley, averaging four or five miles in width, to some high snowy peaks overhanging Lake Yeshil-kul at its western extremity. The range bounding this Pamir on the north is free of snow in summer, but that separating it from the Great Pamir is of considerable height, the summits are always covered with snow, and the passes across it difficult. Traces of ancient glaciers are very frequent, and the western end near Lake Yeshil-kul is choked up with their moraines, forming a sea of gravel mounds, in the hollows of which numerous lesser lakes may be seen. On the borders of Yeshil-kul, at a place called Somatash, Captain Younghusband found the fragments of a stone,bearing an ancient inscription in Turki, Chinese, and Manchu. This interesting relic, as far as Captain Younghusband has been able to get the rubbings he took of it translated, refers to the expulsion of the twn Khojas from Kashgar by the Chinese in 1759 , and relates how they were pursued to the Badakhshan frontier.

From the Ak-su Valley the two traveliers ascended the sterile valley of the Ak-baital, which at th is season of the year (October) has no water in it, and visited Lake Rang-kul. "On the edge of this lake is a prominent outstanding rock, in which there is a cave with what appears to be a perpetual light burning in it. This rock is called by the natives Chiragh-tash, i.c. the Lamp Rock, and they account for the light by saying that it comes from the eye of a dragon which live: in the cave. This interesting rock naturally excited my curiosity. From below I could see the light quite distinctly, and it seemed to come from some phosphorescent substance. I asked the Kirghiz if any one had ever entered the cave, and they replied that no one would dare to risk the anger of the dragon. My Afghan orderly, however, had as little belief in dragons as $\mathrm{I}$ had, and we set off to scale the cliff together, and by dint of taking off our boots and scrambling up the rocks, very much like cats, we managed to reach the mouth of the cave, and on gaining an entrance found that the light came neither from the eye of a dragon nor from any phosphorescent substance, but from the usual source of light-the sun. The cave, in fact, extended to the other side of the rock, thus forming a hole right through it. From below, however, you cannot see this, but only the roof of the cavern, which, being covered with a lime deposit, reflects a peculiar description of light. Whether the superstitious Kirghiz will believe this or not I cannot say, but I think the probability is that they will prefer to trust to the old traditions of their forefathers rather than the wild story of a hare-brained stranger. The water of Rang-kul is salt, and the colour is a beautiful clear blue. The mountains in the vicinity are low, rounded, and uninteresting; though from the eastern end a fine view of the great snowy Tagarma Peak may be obtained."

The winter was spent in Kashgar. On July 22, 1891, Captain Younghusband left to return to India by way of the Pamirs and Gilgit.

"On reaching the Little Kara kul Lake, a piece of interesting geography, which I believe had been first noticed by Mr. Ney Elias, on his journey through these parts some years ago, presented itself. Captain Trotter, of the Forsyth mission, saw from the plains of Kashgar a stupendous preak, the height of which he found to be 25,300 feet, and the position of which he determined accurately. From Tash-kurgan or its neighbourhood he also saw a high mountain mass in the direction of the peak he had fixed from near Kashgar; bad weather prevented his determining the position of this second peak, but he thought there was no doubt that the two were identical. Such, however, is not the case. There are two peaks, about 20 miles apart, one on either side of the Little Kara-kul Lake. That seen from Tash-kurgan is the true Tagarma Peak, and cannot be seen from Kashgar; while that seen from Kashgar cannot be seen from Tash-kurgan. There appeared to me to be very little difference in height between the two. Both are remarkable not only for their extraordinary height, but also for their great massiveness. They are not mere peaks, but grent masses of mountain, looking from the lake as if they bulged out from the neighbouring plain; and one sees far more distinctly than is usually the case, the layers upon layers of rock which have been upturned like the leaves of a book forced upwards. It struck me too, especially from the appearance of the rocks in the neighbourhood of the northernmost peak, that these must have been upheaved far more recently than the worn-out-looking mountains in the centre of the region of the Pamirs. The appearance of these two great mountain masses rising in stately grandeur on either side of a beautiful lake of clear blue water is, as may be well imagined, a truly magnificent spectacle, and, high as they are, their rise is so gradual and even, that one feels sorely tempted to ascend their maiden summits and view the scene from the loftiest parapets of the "Roof of the World." "

On October 4, Captain Younghusband anct a companion left the Tagh-dum-bash Pamir to explore "an interesting little corner of Central Asia, the point where the two watersheds-the one between the Indus on the south and the Oxus and Eastern Turkistan rivers on the north, and the other between the Oxus on the west and the eastern Turkistan rivers on the east-join. If any point can be called the Heart of Central Asia I should think this must be it. Here on the Oxus side of the watershed are vast snowfields and glaciers, and among these, with three of its sides formed of cliffs of ice-the terminal walls of glaciers-we found 
a small lake, about three-quarters of a mile in width, out of which flowed the stream which joins the Panja branch of the Oxus at Bozai-Gumbaz."

After this Captain Younghusband made his way down to Kashmir.

\section{THE INSTITUTION OF MECHANICAL} ENGINEERS.

$\mathrm{O}^{\mathrm{N}}$ Thursday and Friday evenings of last week, the $4^{\text {th }}$ and 5 th inst., the Institution of Mechanical Engineers held ir forty-fifth annual general meeting in the theatre of the Institution of Civil Engineers, lent for the purpose by the Council of the latter Society, according to custom.

The first business was the reading of the annual report of the Council, from which it appears that the Institution continues to prosper, both in regard to finances and membership. The accumulated surplus now amounts to about $£ 36,000$, and is increasing at the ate of over $£ 2000$ per annum. At the end of last year the number of names of all classes on the roll of membership amounted to 2077 , a net gain of 134 on the previous year.

The following two papers were read and discussed :-

(I) Notes on mechanical features of the Liverpool Waterworks, and on the supply of power by pressure from the public mains, and by other means, by Joseph Parry, water engineer, Liverpool.

(2) On the disposal and utilization of blast-furnace slag, by William Hawdon, of Middlesborougb.

The first paper was chiefly valuable as recording an attempt of the Liverpool Corporation, who control the water supply of the city, to establish a system of power distribution by means of the ordinary mains. The Liverpool water supply is chiefly interesting at the present time from the fact that the Vyrnwy works and connections are all but complete. When this system is in operation the Liverpool mains will carry a pressure of water obtained by a natural head, due to the source of supply being in the higher land of North Wales. At present there are in active duty, in connection with the Liverpool Water-works, some fine examples of veteran pumping-engines. There is a Cornish engine and boiler erected at the Windsor station in $\mathbf{1} 840$; a crank engine made in 1837 ; and a fine old Cornish pumping-engine and boiler made by the celebrated firm of Harvey and Co., of Hayle, in Cornwall. The cylinder of the latter is 50 inches in diameter, with a 9 -foot stroke, and is steamjacketed. The pump is $17 \frac{1}{4}$ inches in diameter by 8 feet 9 inches stroke. The average boiler pressure is 35 pounds per square inch. Since this engine began its career it has lifted $\mathbf{I} 8,854$ million foot-tons of water. By a recent trial its duty was found to be 55.7 millions of foot-pounds per cwt. of coal. The indicated horse-power is about 86. The figures serve to show that, in spite of higher pressures and quicker piston-speeds, now so much talked of, not so much advance has been made in the economy of big engines as one might be led to suppose from the efforts that are made to introduce three and four stage compounding, and the virtues that are attributed to it. The average rate of water supply of Liverpool per head per day is about $24 \frac{1}{2}$ gallons, and the water is distributed on the constant service system. Mr. P. Howden's figures as to cost of various systems of power supply are valuable, but they would have been rendered still more so had he taken the further trouble of introducing a more crderly system of classification, and had he given, in one or two instances, fuller information as to the elements upon which he had based his calculations. However, we must not look our gift horse too curiously in the mouth, and any information on one of the great problems of the hourcommon power supply from central stations-is to be made the most of at present. No doubt civilization has lagged behind somewhat in this respect. Power "laid on" in our houses might be as much a matter of course as the bringing of gas and water to us by automatic means; and doubtless this would do something towards solving that other great problem of the hour -and most other hours-the domestic servant problem. At present nearly all large buildings in London, and still more so in America, have a fairly large power installation in their basements. The number of steam boilers that are hidden away among the foundations of large hotels, clubs, and stacks of offices would surprise many people not familiar with these matters. All this involves some waste of room and some waste of energy. In New York a few months ago an effort was made to solve the problem of power distribution by generating steam in a gigantic battery of boilers in one central station, and running the steam pipes all over the city; so that one had only to open a valve and the steam engine could be started forthwith. The scheme was not altogether a success. After a very short time New Yorkers were disagreeably surprised by artificial geysers and mud fountains springing up in the middle of some of the most frequented thoroughfares. A great outcry was raised, and for some time it seemed as if popular indignation would compel the company to stop their work. We believe, however, that there have been improvements lately, but it does not seem probable that steam, conveyed in pipes, will be the means by which power distribution will find its solution in England. Compressed air possesses strong advocates, and in Paris the Popp system, originally devised simply for working clocks from a common centre, has proved a success. In England, however, we have the recent failure at Birmingham, where much money has been spent and many disappointments caused by an endeavour to supply compressed air for power purposes in the city, which, perhaps, of all others in the world, offers the most promising field for such an enterprise. The Hydraulic Power Company has proved a success in London, and its ramifications extend over a wider area than most people imagine; but here, we think, the enterprise finds by far its greatest outlet simply in working elevators and lifts. The gas companies are the largest distributors of power. Perhaps the keenest struggle for lighting and supplying domestic power will be between gas and electricity. The latter has the advantage, from a power point of view, that the motor is clean, compact, odourless, and comparatively noiseless. There is no denying that the gas-engine is not a pleasant neighbour. It is also difficult to start, and requires a large water supply; it smells badly, and makes a noise. On the other hand, it is far cheaper than electricity. Mr. Parry, in his paper, gives an instance of a gas-engine working a hoist in Liverpool at the cost of one-third of a penny per indicated horse-power per hour, and this we should not class as a low figure by any means; whilst Sir James Douglass stated that the charge made for the same unit of power by the Liverpool Electric Supply Company was $5 d$. per hour. There is one other source of power which is yet in its extreme infancy, but of which, we think, much will be heard before long. That is the oil-engine. It cannot be brought into the category of power distribution, however, as each motor of this kind must work on its own bottom. For country districts and isolated positions, at any rate, it offers great promise, and will assuredly take a prominent position when the mechanical details have been brought to a higher state of perfection. The chief interest in Mr. Parry's paper centres in the tables giving figures as to cost. These may be briefly summed up in the statement that when water at high pressure ( 700 pounds) can be bought for $5 s$. per thousand gallons, water power at average domestic pressure (50 to 70 pounds) cannot compete with it. Whether high pressure water will be able to beat electricity and gas is a problem the solution of which is hidden in the future ; and doubtless all the systems mentioned have advantages peculiar to them which would give each in turn the preference under given conditions. Hydraulic distribution has a great point in its favour when the exhaustwater can be used for other purposes.

The disposal of blast-furnace slag would not appear a very interesting question to the uninitiated, but it is really a very important matter. In Great Britain the iron-masters of the country produce annually $12,000,000$ tons of this all but unused material. It is the refuse of iron-smelting, and it may be added that this annual supply of waste matter absorbs, and radiates uselessly into space, heat units which require for their production 653,000 tons of coal. A very small part of this slag is applied to any useful end ; by far the greater quantity of it simply cumbers the ground, or necessitates the spending of large sums in carrying it out to sea. Of course, iron cannot be made without producing slag. To smelt the ore limestone has to be used in order to separate the various impurities with which it is blended. In this way the slag is produced, and the purer metal is obtained. Mr. Hawdon has devised a machine by which he claims to have facilitated the removal and utilization of the slag. In general principle it is not altogether novel, but it possesses some features which, its inventor claims, renuer its working a success, whereas failure has hitherto accompanied such efforts. In the blast furnace the molten slag separates from molten

NO. I I 63 , VOL. 45] 